\title{
Training Mode on Innovative Talents in Universities
}

\author{
RUI LIU \\ School of Accounting \\ Taihu university of Wuxi \\ Wuxi, China
}

\begin{abstract}
For the cultivation of innovative talents, this paper takes accounting major as an example, compares the training mode of innovative talents in Europe and the United States, and then proposes a new mode of talent cultivation based on the existing problems in China called "theory + practice + theory". Under this mode, an innovative talent training model is constructed; innovative ability is improved from the four perspectives of scientific research, teaching methods, innovative projects and university-enterprise cooperation, which serves the community better.
\end{abstract} talent

Keywords-Accounting major; talents cultivation; innovative

\section{INTRODUCTION}

With the in-depth development of China's market economy, diversified talents have become new market demands. At present, requirement for talents has gradually changed from the original professional talents to the applied talents. It can be seen that the demand for applied talents is gradually expanding, requires higher education institutions to focus on applicability, pragmatism and operability as training disciplines, which is called the "theory + practice" talent training mode. On one hand, it teaches students theoretical knowledge directly, so that students have an understanding of what they have learned. This is the most widely used teaching method. However, on the other hand, students do not know where the theoretical knowledge in the book should be used. It reflects the importance of practice. This kind of talent training mode is to train students to apply the professional knowledge and skills they have learned in the school to the future work.

However, with the higher requirements of applied talents, enterprises are also gradually paying attention to the innovation ability of talents, observing whether they can bring fresh "blood" to enterprises that enhance their competitive advantage. In this regard, society requires universities to concern more about training innovative talents. Innovative talents are outstanding in their innovative ability and transform their knowledge into new ideas, new methods, and new concepts [1]. Therefore, innovative ability is the driving force for economic and technological development. As far as China is concerned, most universities put less concentration on the cultivation of innovative talents. Compared with European and American countries, the innovative talent training mechanism is still improving. For the United States, the curriculum is highly flexible and adjusts to meet the needs of national and social development [2]. The UK focuses on a student-centered, teacher-assisted training mode [3]. Therefore, for the cultivation of innovative talents in China, new training modes need to be proposed and applied. Under this new training talent mode, innovative talent training programs have also been proposed accordingly.

\section{THE NEW MODE OF TALENT CULTIVATION IN "THEORY + PRACTICE + THEORY"}

In terms of the current goal of talent training in universities, not only the students' professional knowledge is emphasized, but also the diversified talent characteristics of students' pragmatism, operability and innovation in their future work. Thus, training talent mode can be further optimized from the previous training mode. It can be found that the "theory + practice" talent training mode has been proposed and applied many times. This mode is to learn professional theoretical knowledge at the beginning, and then go to the corporate internship to enhance students' practical ability. However, students are not very purposeful in the early stage of learning professional knowledge, they are not clear about where these professional theoretical knowledge is applied. Once students are for internships, they will encounter bottlenecks in their practical work because their mastery of professional knowledge is not solid. In this case, the time of theoretical study and practice should be reasonably planned. For example, practice can be arranged in the summer of sophomores and juniors. After that, when students return to the campus with professional problems that encountered in practical work, they are more willing to deepen their theoretical knowledge, which improve their learning efficiency and initiative. At the same time, the practical work engaged in the enterprise will also stimulate students to have innovative ideas for future work. Therefore, the optimization of the talent training mode is called "theory + practice + theory" [4].

Taking the accounting major as an example, this new mode is divided into four stages according to the learning time (see Fig. 1): freshman, sophomore, junior, senior. 


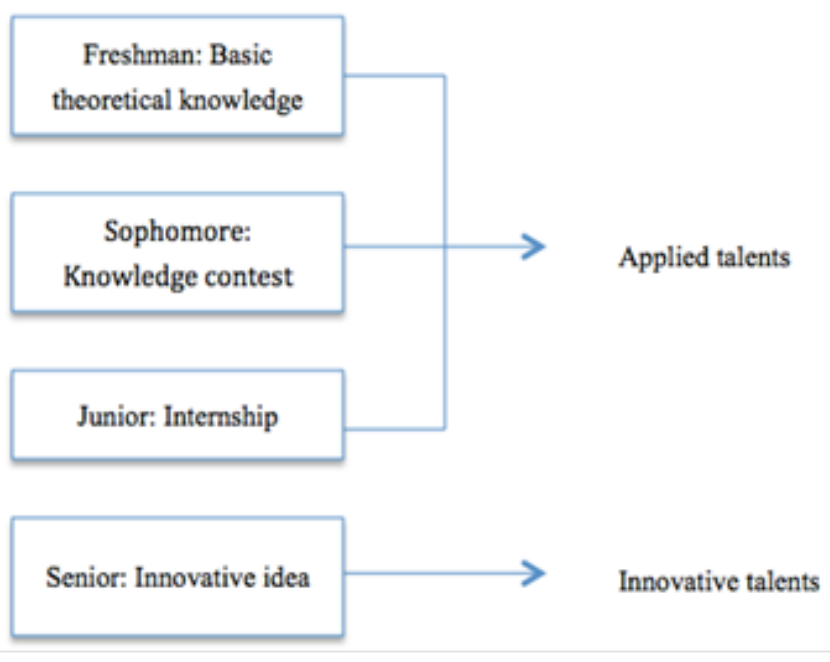

Fig. 1. Talent training mode

As shown in the above-mentioned talent cultivation stage, in the first stage, students are just entering universities, basic theoretical modules are widely arranged, so that students can have a general understanding of accounting majors they have learned, and slowly transit to the next stage. In the second stage, students should have an in-depth understanding of accounting knowledge and participate in a series of related practical activities such as knowledge competitions to promote their mastery of professional knowledge and their enthusiasm. In the third stage, students should continue to improve their practical ability rather than just participation. Accounting major is a discipline with strong practical ability. If students only have theoretical knowledge, they will have bottleneck in future practical work. Therefore, universities strengthen universityenterprise cooperation, which provide summer internship opportunities. It enables students to truly participate in practical work, and then strengthen professional knowledge they have learned. In the final stage, students will propose innovative ideas for their practical work. Therefore, it can be seen that the new talent training mode is suitable for the cultivation of innovative talents, and the application talents are ultimately paving the way for the cultivation of innovative talents.

\section{TRAINING PROGRAM FOR INNOVATIVE TALENT}

\section{A. Innovative Talent Training Model Construction}

Under this new training talent mode, which aspects to cultivate innovative talents is the next step. At present, universities have not yet developed a sound training content. In terms of curriculum setting, teaching methods, and universityenterprise cooperation, the innovative talent training is not as good as the applied talent training. Therefore, according to the existing problems of cultivating innovative talents in China, a model for innovative talents has been constructed (see Fig. 2).

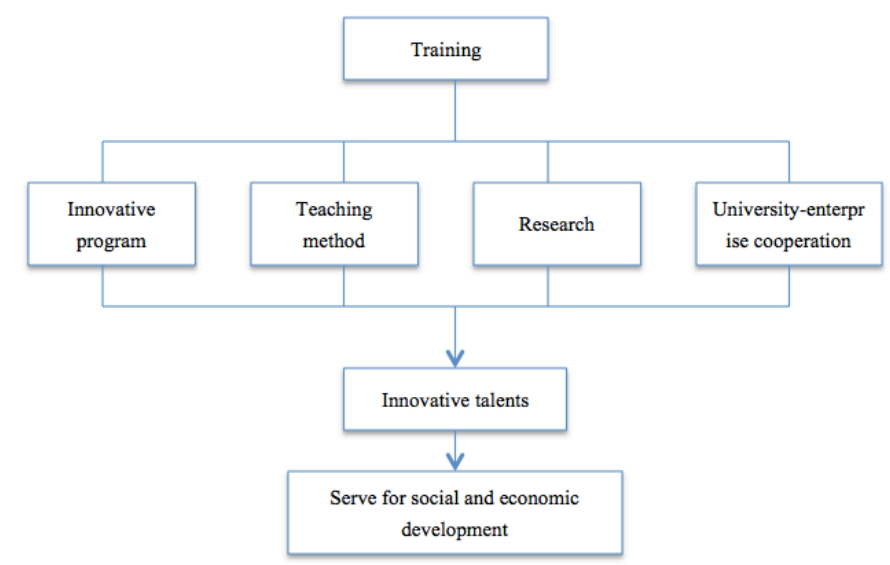

Fig. 2. Innovative talent training mode

\section{B. Construction of University-enterprise Cooperation Projects}

The essence of establishing cooperation between enterprises and university is to carry out dynamic teaching reforms. Both of them form an interactive "on-campus teaching, off-campus guidance" teaching team, so that students can participate in off-campus practice. For the traditional teaching mode, transmission of professional knowledge has a hysteresis quality. The talents cultivated with the knowledge of the university for four years still have to go through the internship period to meet the requirements of the enterprise. After all, students' knowledge from books is not well used in practical work. Even if universities open on-campus experimental courses, it only strengthens students' theoretical knowledge and practical ability. When they are actually in practical work, many students still have bottlenecks. At this time, employing entrepreneurs and accounting professionals as external teachers is to participate in the formulation and improvement of talent training programs. On one hand, cooperation between universities and enterprises can make students keep the latest needs of accounting talents and consider about their future career development. On the other hand, universities hire entrepreneurs and accounting professionals to give lectures for students about professional knowledge and employment direction, combined with the experts' own work experience and academic knowledge to break the students' fixed thinking mode. For example, the design of graduation dissertation creates more divergent thinking. It can be combined with the actual cases shared by experts to conduct academic research, which truly reflects the cultivation of innovative talents. In addition, the choice of a cooperative enterprise should be more professionally targeted. The universities should strengthen cooperation with accounting firms, banks, taxation firms, and other firms related to accounting majors. The two sides sign an agreement and send students to firms for internships. In this way, by building university-enterprise cooperation, students are provided with more off-campus practices, so that students actually participate in the actual work, and then get new inspiration from the work. 


\section{Establishing University Students' Innovation and Entrepreneurship Training Program}

At present, China's industrial structure is constantly changing, and mass entrepreneurial vitality emerges, which has led to an increase in the demand for innovative talents in the market. It can be seen that having innovative ideas and abilities has become a step to serve the society better [5]. In this regard, for the cultivation of innovative talents, universities should treat the students as the center and give full play to students' initiative and creative thinking. On this basis, universities further develop students' practical ability and innovative ability. Therefore, during the second or third year of the university, universities should hold more activities such as students innovation and entrepreneurship projects or professional knowledge competitions. Students can choose different practical themes according to their own interests, major and future career orientation. On one hand, students apply professional knowledge to practice. On the other hand, through the innovation and entrepreneurship training program, cultivate the transformation of students' thinking. This new capability shows that education is constantly being promoted, and the talent training model is constantly being reformed. Innovative talents will become a new focus of universities.

\section{Promote Professional Development Projects for Teachers}

Students transform from professional talents to innovative talents not only rely on their own efforts. At the same time, teachers are also a bridge to stimulate students to become innovative talents. Teachers must be strict with their own requirements, whatever their theoretical knowledge reserves, practical application ability or academic research ability. Some universities have proposed "double-type" teachers, which must have the quality of theoretical teaching, but also have the quality of practical teaching, embodying the "theory + practice" talent training mode. However, the cultivated students' ability is limited within the scope of knowledge and practice, it does not have innovation ability. This requires teachers to start from their own and then stimulating students' innovative spirit. Universities can encourage teachers to go to relevant accounting firms to work. When returning to the classroom, teachers can make a case from their own practice to allow students to analyze through the professional knowledge they have learned. Since there are no standard solutions in actual cases, their innovation ability can be stimulated.

In addition, teachers' innovation ability can be cultivated from research projects. Scientific research projects focus on academic innovation. If teachers can actively apply for scientific research and learn from the innovation in academic research, students and teachers can both benefit from it. On one hand, teachers can improve their own research level. On the other hand, teachers' inspiration from research projects can drive students' innovative interest. The professional problems in scientific research allow students to participate in analyzing and effectively improve students' ability to solve problems, which discovers new ideas, new methods and new theories.

\section{CONCLUSION}

Universities should further clarify the goal of talent training. The accounting majors should adhere to the market demandoriented, and carry out the training concept of innovation ability in the process of accounting professional construction, break the traditional talent training mode, and then cultivate a new generation of innovative talents. This paper has formed the goal of "serving for local economic and social development, meeting the needs of enterprises, enhancing employment adaptability and improving talents' innovation ability" [6]. Therefore, universities should always pay attention to the changes in the demand for talents, and timely make corresponding curriculum adjustments and practical work to provide strong talent support for social and economic development.

\section{REFERENCES}

[1] Y. Liu, "On reform of Innovative Talent Cultivation Mechanism for postgraduate in China”, Journal of Graduate Education, vol.6, pp.14-22, 2017. (In Chinese).

[2] S. S. Wang, "Viewing the Cultivation of Innovative Talents from the Characteristics of American Higher Education”, Journal of University Education Management, vol.3, pp67, 2012. (In Chinese).

[3] Z. F. Dong \& C. Yuan, "Experience and Enlightenment of Successfully Cultivating Innovative Talents in Foreign Universities_-Taking Harvard University, Oxford University and the University of Tokyo as examples”, Journal of Modern University Education, Vol.4, pp26-32, 2014. (In Chinese).

[4] C. Jin \& W. C. Huang, "The design of a new model for the application of talents in fiscal and taxation management-Taking Taihu university of Wuxi as an example”, Journal of China Off-campus Education, vol.30, pp65-66, 2017. (In Chinese).

[5] X.Li, "Analysis of the Influence of Pre-school Education on the Innovation Ability of High-level Talents”, Journal of Graduate Education Research, vol.2, pp30-32, 2014. (In Chinese).

[6] Z. J. Wu \& C. L. Huang, "The Connotation of Applied Talents and the Cultivation of Applied Undergraduate Talents", Journal of Higher Education Research, vol.2, pp66-70, 2014. (In Chinese). 